Volume 5 Issue 1, March 2020: pp. 25-41. Copyright @ LamLaj. Faculty of Law, Lambung Mangkurat University, Banjarmasin, South Kalimantan, Indonesia. ISSN: 2502-3136 | e-ISSN: 2502-3128. Open Access at: http://lamlaj.ulm.ac.id

\title{
JANJI KAWIN DALAM PERSPEKTIF HUKUM PERDATA
}

\author{
Abdul Halim Barkatullah', ${ }^{1}$ Tavinayati $^{2}$ \\ Faculty of Law, University of Lambung Mangkurat \\ Jl.Brigjen H. Hassan Basry Banjarmasin 70124 \\ Telp/Fax:+62-4321658Email:ahbarkatullah@ulm.ac.id \\ Faculty of Law, University of Lambung Mangkurat \\ Jl.Brigjen H. Hassan Basry Banjarmasin 70124 \\ Telp/Fax:+62-4321658Email: tavina.yati2018@gmail.com
}

\begin{abstract}
A$ breach promise to marry causes a material and immaterial loss for a woman so that she sues the man to compensate and recover his good name for the inner suffering he has. The aim of this research is to find out the basis of the lawsuit of the promise to marry and to find out the judge's consideration in the case concerning the promise to marry. This research is a normative juridical study with a type of legal obscurity research using a statutory approach. Besides that, the concept approach is also used. The concept of promise to marry, marriage annulment and marriage agreements. The case approach is also used in this study because it will criticize court decisions related to promise to marry. This is a prescpiptive research. The results showed: The act of breaking of promise to marry is an act against the law, this refers to the provisions of Article 58 of the Civil Code, Therefore, the basis of the lawsuit must fullfil the elements contained in Article 1365 of the Civil Code. The considerations used by judges in the case of promise to marry are the interpretations against the law in a broad meaning, including actions which are contrary to the norms of morality and propriety in society.
\end{abstract}

Keywords: promise to marry; civil law

Abstrak: Janji kawin yang diingkari menimbulkan kerugian materiil dan immateriil bagi seorang wanita, sehingga ia menggugat si laki-laki untuk memberikan kompensasi dan pemulihan nama baik atas penderitaan bathin yang dideritanya. Tujuan yang ingin dicapai dalam penelitian ini adalah untuk mengetahui dasar gugatan dari janji kawin serta untuk mengetahui pertimbangan hakim dalam perkara yang menyangkut janji kawin. Penelitian ini merupakan penelitian yuridis normatif dengan tipe penelitian kekaburan hukum dengan pendekatan perundang-undangan. 
Selain itu digunakan juga pendekatan konsep. Konsep tentang janji kawin, pembatalan perkawinan dan perjanjian perkawinan. Pendekatan kasus digunakan juga dalam penelitian ini karena akan mengkritisi putusan-putusan pengadilan terkait janji kawin. Sifat penelitian adalah preskriptif. Hasil penelitian menunjukan bahwa perbuatan mengingkari janji kawin merupakan perbuatan melawan hukum, hal ini merujuk pada ketentuan Pasal 58 Kitab Undang-undang Hukum Perdata. Oleh karena itu, dasar gugatannya harus memenuhi unsur-unsur yang terdapat dalam Pasal 1365 Kitab Undang-undang Hukum Perdata. Pertimbangan yang digunakan hakim dalam kasus janji kawin merupakan penafsiran melawan hukum dalam arti yang luas, yaitu termasuk perbuatan yang bertentangan dengan norma kesusilaan dan kepatutan dalam masyarakat.

Kata kunci: Hukum Perdata; Janji Kawin.

\section{PENDAHULUAN}

Gugatan terkait janji kawin yang tidak ditepati akhir-akhir ini banyak masuk ke pengadilan. Janji kawin yang dimaksud disini adalah janji seorang laki-laki untuk mengawini seorang perempuan yang merupakan kekasihnya. Atas dasar janji tersebut siwanita bersedia untuk menuruti semua keinginan kekasihnya. Si laki-laki kemudian mengingkari janjinya, wanita yang dikhianati tersebut merasa harkat dan martabatnya sebagai seorang perempuan dirugikan sehinggamemutuskan untuk mengajukan gugatan ke pengadilan.

Dasar gugatan perdata ada dua macam, yakni: wanprestasi dan perbuatan melawan hukum. Wanprestasi/ingkar janji merupakan suatu perbuatan yang dari seseorang yang tidak memenuhi janji atau prestasinya sebagaimana yang sudah disepakati para pihak. Sedangkan perbuatan melawan hukum adalah suatu perbuatan yang melanggar ketentuan hukum baik hukum tertulis (undang-undang), maupun hukum tidak tertulis yakni perbuatan yang bertentangan dengan kesusilaan ataupun bertentangan dengan kepatutan yang berlaku di masyarakat. Akibat perbuatan melawan hukum sebagaimana halnya wanpresta- si adalah terbitnya kerugian bagi pihak lain yang haknya dilanggar. Pihak yang dirugikan tentu ingin haknya dipulihkan.

Secara teori, wanprestasi dan perbuatan melawan hukum memang dapat dibedakan, akan tetapi dalam praktik sering terjadi kerancuan. Gugatan yang seharusnya didasarkan pada wanprestasi, digugat atas dasar perbuatan melawan hukum begitu juga sebaliknya. Beberapa putusan pengadilan kadang juga tidak secara tegas membedakan kedua hal tersebut.

Apa sebenarnya perbedaan hakiki antara perbuatan melawan hukum dengan wanprestasi ? Apakah janji kawin itu merupakan wanprestasi atau perbuatan melawan hukum? Bagaimana hakim memaknai ketentuan Pasal 58 Kitab Undang-undang Hukum Perdata (Staatsblad Tahun 1847 Nomor 23; untuk selanjutnya disebut KUH Perdata) menyatakan: (1) Janji-janji kawin tidak menimbulkan hak guna menuntut dimuka hakim akan berlangsungnya perkawinan, pun tidak guna menuntut penggantian biaya, rugi dan bunga, akibat kecederaan yang dilakukan terhadapnya, segala persetujuan untuk ganti rugi dalam hal ini adalah batal.

(2) jika namun itu pemberitahuan kawin ke- 
pada pegawai pencatatan sipil telah diikuti dengan pengumuman kawin, maka yang demikian itu dapat menimbulkan alasan guna menuntut pergantian biaya,rugi dan bunga berdasar atas kerugian-kerugian yang nyata kiranya telah diderita oleh pihak satu mengenai barang-barangnya, disebabkan kecederaan pihak lain, dengan sementara itu tak boleh diperhitungkannya soal kehilangan untung.

Berdasarkan latar belakang di atas, permasalahan yang diangkat dalam penelitian ini dirumuskan sebagai berikut: pertama, apa dasar gugatan dalam janji kawin? dan kedua, bagaimana pertimbangan hakim dalam perkara yang menyangkut janji kawin?

\section{METODE}

Penelitian ini merupakan penelitian yuridis normatif dengan tipe penelitian adalah kekaburan hukum tentang janji kawin dalam KUH Perdata, dengan pendekatan perundangundangan. Pendekatan kasus digunakan juga dalam penelitian ini, karena akan mengkritisi putusan-putusan pengadilan terkait janji kawin. Sifat penelitian adalah preskriptif, yakni untuk mendapatkan saran atau petunjuk dalam mengatasi masalah tertentu yang dalam hal ini adalah persoalan janji kawin dalam ketentuan KUH Perdata.

\section{ANALISIS DAN PEMBAHASAN \\ Dasar Gugatan Dalam Kasus Janji Kawin}

Perbedaan hakiki antara wanprestasi dengan perbuatan melawan hukum terletak pada apakah ada konsensus atau kesepakatan antara kedua pihak sebelumnya? Apakah ada hubungan kontraktual sebelumnya atau tidak? Secara umum dipahami bahwa wanprestasi itu terjadi karena salah satu pihak yakni debitur tidak memenuhi prestasinya.
Sedangkan, perbuatan melawan hukum, sesuai dengan Pasal 1233 KUH Perdata adalah perikatan yang lahir dari undang-undang (undang-undang dalam arti luas termasuk hukum tidak tertulis). Suatu perbuatan apakah termasuk perbuatan melawan hukum atau tidak, undang-undang yang menentukan. Jadi, dalam suatu perbuatan melawan hukum tidak ada konsensus sebelumnya antara pihak yang melakukan dengan pihak yang mengalami kerugian akibat perbuatan melawan hukum. Sehubungan dengan hal tersebut, apakah gugatan terhadap tidak dipenuhinya janji kawin tersebut murni persoalan perbuatan melawan hukum? atau dapat juga digugat berdasarkan wanprestasi?

Semua berawal dari ketentuan Pasal 58 KUH Perdata yang menjadi dasar apakah tidak dipenuhinya janji kawin itu merupakan wanprestasi ataukah perbuatan melawan hukum. Pasal 58 ayat (1) KUH Perdata menyatakan, bahwa "janji-janji kawin tidak menimbulkan hak guna menuntut dimuka hakim akan berlangsungnya perkawinan, pun tidak guna menuntut penggantian biaya, rugi dan bunga, akibat kecederaan yang dilakukan terhadapnya, segala persetujuan untuk ganti rugi dalam hal ini adalah batal." Dari bunyi ayat (1) Pasal $58 \mathrm{KUH}$ Perdata tersebut, apabila ditelaah mengandung dua unsur, yakni: (a) pihak yang dirugikan tidak dapat menuntut pihak lain di depan pengadilan agar memenuhi janjinya untuk melangsungkan perkawinan seperti yang sudah dijanjikannya; dan (b) pihak yang dirugikan akibat tidak dipenuhinya janji kawin tidak dapat menuntut pergantian kerugian dalam bentuk biaya, rugi dan bunga. Tuntutan terhadap hal itu tidak ada gunanya atau batal. Dari dua unsur yang dapat ditarik pada ayat (1) Pasal 58 KUH Perdata tersebut, menunjukan bahwa tidak dipenuhinya janji 
kawin bukan merupakan tindakan wanprestasi, oleh karena itu, tuntatan ganti rugi akibat tidak dipenuhinya janji kawin tidak akan dikabulkan.

Pembentuk undang-undang tidak memasukan janji kawin yang diingkari sebagai wanprestasi. Bukankah itu merupakan sebuah janji, sebuah kesepakatan. Bukankah berdasarkan asas kekuatan mengikat atau asas pacta sunt servanda, janji itu mengikat sebagaimana mengikatnya sebuah undangundang bagi yang membuatnya seperti yang ditegaskan dalam Pasal 1338 ayat (1) KUH Perdata. Apabila salah satu pihak tidak memenuhi prestasinya, maka ia dikatakan wanprestasi? Pasal 1267 KUH Perdata mengatur sanksi bagi debitur yang lalai, yakni: apakah menuntut pemenuhan perjanjian, pemenuhan perjanjian disertai ganti rugi, ganti rugi, pembatalan perjanjanjian ataukah pembatalan perjanjian disertai ganti rugi. Apabila melihat ketentuan Pasal 1267 KUH Perdata, seyogianya korban dapat menuntut pemenuhan prestasi berupa pelaksanaaan perkawinan seperti yang sudah dijanjikan. Pengingkaran terhadap hal tersebut merupakan wanprestasi. Akan tetapi sebelum pada kesimpulan tersebut, tentu harus dilihat dulu apakah janji kawin tersebut memenuhi unsur-unsur syarat sahnya suatu perjanjian, sehingga perjanjian tersebut mengikat para pihak yang membuatnya.

Sebuah perjanjian itu mengikat bagi para pihak yang membuatnya tentu harus memenuhi unsur yang terdapat dalam Pasal 1320 KUH Perdata yaitu:

a. Adanya kesepakatan antara kedua belah pihak yang mengadakan perjanjian. Janji kawin memenuhi unsur sepakat antara 2 pihak. Seandainyapun, mengandung unsur dwaling, dwang dan bedrog pun itu tetap mengikat kalau tidak dimintakan pembatalannya di muka hakim.

b. Kecakapan para pihak yang membuat perjanjian. Unsur cakap tentu terpenuhi apabila para pihaknya sudah dewasa, apabila masih dibawah umur maka diwakili oleh orangtua atau wali. Sama dengan unsur sepakat meskipun tidak terpenuhi maka perjanjian yang dilakukan oleh mereka yang tidak cakap tetap sah apabila tidak diminta pembatalannya di muka hakim.

c. Suatu hal tertentu. Merupakan obyek perjanjian:

- Obyek perjanjian hanyalah barangbarang yang dapat diperdagangkan (Pasal 1332 KUH Perdata);

- Obyeknya tidak dilarang undang-undang

Dilihat dari obyek perjanjian, janji kawin tidak memenuhi unsur suatu hal tertentu. Hal ini tidak mengherankan karena perjanjian yang dimaksudkan disini adalah perjanjian dalam lapangan hukum harta kekayaan, sehingga obyeknya adalah barangbarang yang dapat diperdagangkan. Janji kawin masuk ruang lingkup hukum keluarga berarti bicara hubungan personal, bukan hubungan kreditur dan debitur. Ingkar janji terhadap janji kawin bukan perbuatan wanprestasi.

d. Causa yang halal

- Merupakan sebab/dasar dibuatnya suatu perjanjian

- Suatu sebab adalah halal jika tidak bertentangan dengan undang-undang, ketertiban umum dan kesusilaan.

Sebuah janji kawin tidaklah bertentangan dengan peraturan perundangan-undangan, ketertiban umum dan kesusilaan. Hal yang demikian adalah hal yang lumrah dalam suatu hubungan. Apabila kemu- 
dian janji kawin tersebut diingkari dan ada pihak yang jadi korban karena menderita kerugian materiil maupun immateriil maka si korban dapat menggugat pelakunya. Dasar gugatannya bukan wanprestasi karena bertentangan dengan ketentuan Pasal 58 ayat (1) KUH Perdata.

Janji kawin tidak memenuhi unsur yang terdapat dalam Pasal 1320 KUH Perdata khususnya unsur ketiga dan keempat, maka pengingkaran terhadap janji kawin bukanlah perbuatan wanprestasi. Pasal 58 ayat (1) KUH Perdata menegaskan bahwa tidak dipenuhinya janji kawin bukanlah wanprestasi. Sebuah perjanjian yang tidak memenuhi unsur obyektif yakni suatu hal tertentu dan causa yang halal maka perjanjian tersebut batal demi hukum. Dengan demikian, maka gugatan terhadap janji kawin yang diingkari hanya dapat digugat berdasarkan perbuatan melawan hukum.

Kriteria utama, apakah telah terjadi perbuatan melawan hukum atau tidak dapat dilihat dari pertanyaan apakah telah terbit kerugian atau tidak? Apabila terbit kerugian, maka apakah keempat unsur perbuatan melawan hukum terpenuhi atau tidak. Apabila salah satu unsur tidak terpenuhi maka ketentuan Pasal 1365 KUH Perdata tidak dapat diterapkan. Rumusan Pasal 1365 KUH Perdata mengandung 4 (empat) unsur yakni: (1) ada perbuatan melawan hukum; (2) ada kesalahan (schuld); (3) ada kerugian (schade); dan (4) ada hubungan kausal antara kerugian dengan perbuatan.

Dilihat dari unsur pertama, ingkar janji terhadap janji kawin dapat dikategorikan sebagai perbuatan melawan hukum dalam bentuk pelanggaran terhadap norma kesusilaan dan kepatutan di masyarakat. Pada kasus Masudiati versus Gusti Lanang Rejeg, perbuatan
Gusti Lanang Rejeg dipandang melanggar norma kesusilaan dan kepatutan di masyarakat, dengan janji akan menikahinya, ia mengajak Masudiati untuk hidup bersama tanpa ikatan perkawinan. Hidup bersama tanpa ikatan pernikahan adalah perbuatan tercela, melanggar tata susila di masyarakat, melanggar hukum adat setempat.

Putusan hakim ini sejalan dengan pendapat Wirjono Prodjodikoro, bahwa sifat perbuatan melawan hukum apabila perbuatan itu mengakibatkan kegoncangan dalam neraca keseimbangan dalam masyarakat. Dan kegoncangan ini tidak hanya terdapat, apabila peraturan-peraturan hukum dalam suatu masyarakat dilanggar (langsung), melainkan juga, apabila peraturan-peraturan kesusilaan, keagamaan dan sopan santun dalam masyarakat dilanggar (langsung). Bagi Indonesia hal ini tidak begitu sulit, oleh karena dalam $\mathrm{Hu}-$ kum Adat ada suatu persamaan corak diantara peraturan-peraturan hukum disatu pihak dan peraturan-peraturan kesusilaan, keagamaan dan sopan santun dilain pihak, yakni semua peraturan-peraturan itu tidak termuat dalam suatu undang-undang, sehingga para penguasa, terutama para Hakim tidak begitu terikat pada kata-kata, yang terpaku dalam suatu undang-undang. Dengan demikian para Penguasa itu lebih berkesempatan untuk benar-benar memperhatikan rasa keadilan, yang pada tiap waktu berada dalam dada para anggota masyarakat tentang suatu hal yang tertentu). ${ }^{1}$

Apakah ingkar janji terhadap janji kawin memenuhi unsur kesalahan? Perbuatan demikian mengandung kesalahan dalam bentuk kesengajaan dimana pelaku yang menjanjikan perkawinan tersebut menyadari

1 Wirjono Prodjodikoro. 2000. Perbuatan Melanggar Hukum Dipandang Dari Sudut Hukum Perdata. Cet.1. Bandung: Mandar Maju, hlm.7 
sepenuhnya akan ada akibat dari perbuatan tersebut. Oleh karena itu, ia harus bertanggungjawab atas perbuatannya tersebut. Hal yang paling penting dalam perbuatan melawan hukum adalah apakah korban menderita kerugian dari perbuatan melawan hukum tersebut? Ada 3 bentuk ganti rugi terhadap perbuatan melawan hukum yang dikenal oleh hukum adalah $)^{2}$ sebagai berikut:

1. Ganti rugi nominal

Jika ada perbuatan melawan hukum yang serius seprti perbuatan yang mengandung unsur kesengajaan tetapi tidak menimbulkan kerugian yang nyata bagi korban, maka kepada korban dapat diberikan sejumlah uang tertentu sesuai dengan rasa keadilan tanpa menghitung berapa sebenarnya kerugian tersebut.

2. Ganti rugi kompensasi/aktual

Merupakan ganti rugi yang merupakan pembayaran kepada korban atas dan sebesar kerugian yang benar-benar telah dialami oleh pihak korban dari suatu perbuatan melawan hukum.Karena itu, ganti rugi seperti ini disebut juga dengan ganti rugi actual. Misalnya, ganti rugi atas segala biaya yang dikeluarkan oleh korban. Kehilangan keuntngan/gaji, sakit dan penderitaan, termasuk penderitaan mental seperti stress, malu, jatuh nama baik, dan lain-lain.

\section{Ganti rugi penghukuman}

Merupakan suatu ganti rugi dalam jumlah besar yang melebihi dari jumlah kerugian yang sebenarnya. Besarnya jumlah ganti rugi tersebut dimaksudkan sebagai hukuman bagi si pelaku. Ganti rugi ini layak

2 Munir Fuady. 2010. Perbuatan Melawan Hukum Pendekatan Kontemporer. Bandung: Citra Aditya Bakti, hlm.134-135. diterapkan pada kasus-kasus kesengajaan yang berat atau sadis. Misalnya terhadap penganiayaan berat atas seseorang tanpa rasa perikemanusiaan.

Berkenaan dengan bentuk ganti yang kedua yaitu ganti rugi aktual yang didalamnya termasuk ganti rugi karena penderitaan mental, seperti rasa sakit, rasa malu, stress,jatuhnya nama baik, rasa takut yang berlebihan, paling tepat diterimakan pada wanita yang merupakan korban dari janji kawin yang diingkari. Ganti rugi ini dalam praktek dikenal dengan istilah ganti rugi immateriil. Ganti rugi immateriil ini merupakan pemberian sejumlah uang yang jumlahnya tidak dapat diperhitungkan secara matematis, tetapi lebih merupakan kebijaksanaan hakim, tetapi juga dengan syarat bahwa jumlah tersebut bergantung kepada banyak hal antara lain sebagai berikut ${ }^{3}$ :

1. Beratnya beban mental yang dipikul oleh korban

2. Status dan kedudukan dari korban

3. Situasi dan kondisi dimana perbuatan melawan hukum terjadi

4. Situasi dan kondisi mental korban

5. Situasi dan kondisi mental dari pelaku

6. Latar belakang dilakukannya perbuatan melawan hukum

7. Jenis perbuatan melawan hukum, yakni apakah kesengajaan, kelalaian atau tanggungjawab mutlak.

Kerugian yang diderita wanita korban janji kawin dapat berupa kerugian materiil dan immateriil. Pada kasus Masudiati vs Gusti Lanang Rejeg, Masudiati mengalami kerugian materiil karena ia yang menanggung biaya selama hidup bersama Gusti Lanang Rejeg. Demikian juga dalam kasus pembatalan perkawinan antara Lyaniza Meliza Buntu vs Daud Suryaningrat Tarupadang, Lyaniza su-

3 Ibid, hlm.142-143 
dah mengeluarkan sejumlah biaya untuk persiapan perkawinan yang kemudian dibatalkan sepihak oleh pihak laki-laki. Kerugian terbesar yang diderita wanita korban janji kawin adalah kerugian immateriil berupa rasa malu karena jatuhnya nama baik. Sudah seharusnya para wanita tersebut mendapat kompensasi sebagai pemulihan terhadap kehormatan dan nama baiknya.

Dilihat dari unsur keempat maka terdapat hubungan kausalitas antara janji kawin dengan kerugian yang diderita korban. Akibat bujuk rayu berupa janji kawin maka si wanita bersedia menuruti keinginan si lelaki. Tanpa ada janji kawin tentu si wanita tidak bersedia melakukan sesuatu yang diminta laki-laki pasangannya. Kerugian yang paling nyata diderita si wanita adalah rusaknya kehormatan dan nama baiknya dimata masyarakat. Dengan menggugat si laki-laki maka terdapat pemulihan nama baik dan kehormatannya di masyarakat. Pasal 58 ayat (2) KUH Perdata menyatakan, bahwa jika namun itu pemberitahuan kawin kepada pegawai pencatatan sipil telah diikuti dengan pengumuman kawin, maka yang demikian itu dapat menimbulkan alasan guna menuntut pergantian biaya,rugi dan bunga berdasar atas kerugian-kerugian yang nyata kiranya telah diderita oleh pihak satu mengenai barang-barangnya, disebabkan kecederaan pihak lain, dengan sementara itu tak boleh diperhitungkannya soal kehilangan untung. Jelas di sini, bahwa Pasal 58 ayat (2) KUH Perdata menegaskan, apabila janji kawin tersebut ditindaklanjuti dengan rencana perkawinan dan sudah ada pemberitahuan pada pegawai pencatat nikah dan diikuti dengan pengumuman (dalam bentuk undangan perkawinan) tetapi kemudian diingkari maka pihak yang dirugikan dapat menuntut pergantian biaya, rugi dan bunga. Ketiga komponen tersebut merupakan komponen ganti rugi sebagaimana yang dimaksud Pasal 1243-1244 KUH Perdata. Dengan demikian, tindakan membatalkan janji kawin yang sudah diumumkan dan diberitahukan kepada pegawai pencatat nikah merupakan perbuatan melawan hukum dan pihak yang dirugikan dapat menuntut ganti rugi. Kasus pembatalan perkawinan antara Lyaniza Meliza Buntu vs Daud Suryaningrat Tarupadang memenuhi rumusan Pasal 58 ayat (2) KUH Perdata. Dihat dari uraian-uraian diatas maka gugatan terhadap janji kawin yang diingkari hanya dapat digugat atas dasar perbuatan melawan hukum bukan wanprestasi.

\section{Pertimbangan Hakim Dalam Perkara yang Menyangkut Janji Kawin}

\section{Masudiati versus Gusti Lanang Rejeg dalam Putusan Mahkamah Agung No- mor 3191 K./Pdt/1984}

Perkara ini bermula dari janji kawin Gusti Lanang Rejeg terhadap Penggugat Masudiati yang kemudian diikuti dengan hidup bersama. Selama hidup bersama, penggugatlah yang menanggung biaya hidup. Meskipun Penggugat mendesak untuk menikah, Tergugat tidak mau juga menikahinya, hal ini berlangsung hingga 1 tahun 4 bulan. Kemudian penggugat mendesak lagi tetapi tergugat tetap menolak. Oleh karena tergugat tidak memenuhi janjinya untuk mengawini pengggugat maka pengggugat menuntut kerugian yang telah dikeluarkan selama hidup bersama sebesar Rp.1.465.160; dan menuntut pemulihan nama baik sebesar Rp.5000.000. Pengadilan Negeri Mataram melalui Putusan No.073/PN.MTR/ PDT/1983 mengabulkan gugatan Peng- 
gugat dengan pertimbangan hukum: per-

tama, bahwa perbuatan tergugat sebagai seorang laki-laki yang berstatus PNS telah mengajak hidup bersama dengan seorang perempuan (Penggugat) tanpa nikah selama satu tahun 4 bulan, dengan janji akan dinikahi tetapi tdak jadi dinikahi merupakan perbuatan yang telah melanggar hak subyektif orang lain yaitu kehormatan dan nama baik pengggugat yang berstatus sebagai seorang guru dan bertentangan dengan kesusilaan sebagai norma moral yang diakui dalam kehidupan masyarakat, dan bertentangan dengan kepatutan yang berlaku di masyarakat; dan kedua, Pengadilan Negeri berpendapat bahwa perbuatan tergugat tersebut merupakan perbuatan melawan hukum yang menimbulkan kerugian pada orang lain yang mewajibkan kepadanya untuk mengganti kerugian yang ditimbulkan sebagai akibat dari perbuatannya.

Selanjutnya pada tingkat banding, Pengadilan Tingggi Mataram melalui Putusan No.65/Pdt/1984/PT.NTB, membatalkan putusan Pengadilan Negeri diatas dengan pertimbangan hukum, antara lain: pertama, Pengggugat terbanding adalah seorang yang sudah pernah kawin kemudian bercerai dengan suaminya, dengan demikian pada saat mereka berkenalan, pengggugat terbanding adalah seorang janda; kedua, seandainya tergugat pembanding membujuk pengggugat terbanding untuk hidup bersama tanpa kawin, maka penggugat terbanding sebagai seorang yang sudah mengalami perkawinan seharusnya tidak begitu saja menerima bujukan tergugat; dan ketiga, tindakan penggugat terbanding mengambil keputusan untuk hidup bersama Ter- gugat Pembanding serta tinggal dirumah Tergugat Terbanding dengan resiko tidak jadi nikah adalah tanggungan Pengggugat Terbanding sendiri serta tidak dapat dibebankan kepada tergugat pembanding. Berdasarkan pertimbangan diatas, Pengadilan Tinggi berpendapat bahwa tidak terbukti terdapat pencemaran nama baik sehnggga perbuatan terbanding tidak dapat dikatakan sebagai pebuatan melawan hukum.

Dalam tingkat kasasi, Mahkamah Agung menyatakan Tergugat telah melakukan perbuatan melawan hukum dengan pertimbangan sebagai berikut : Bahwa dengan tidak dipenuhinya janji untuk mengawini Tergugat asal telah melanggar norma kesusilaan dan kepatutan dalam masyarakat dan perbuatan Tergugat asal tersebut adalah suatu perbuatan melawan hukum, sehingga menimbulkan kerugian terhadap Pengggugat asal, maka Tergugat asal wajib memberi ganti kerugian

Kasus ini memperlihatkan bahwa janji kawin yang dingkari merupakan perbuatan melawan hukum karena telah menerbitkan kerugian bagi penggugat. Kerugian yang dialami Penggugat lah yang menjadi dasar dari gugatan. Penggugat tidak menuntut tergugat untuk memenuhi janjinya mengawini penggugat tetapi pada akibat tidak dipenuhinya janji kawin telah menerbitkan kerugian bagi penggugat. Ada 2 macam kerugian yang dialami penggugat yakni kerugian materiil berupa biaya hidup yang dikeluarkan penggugat selama hidup bersama tergugat dan kerugian immateriil berupa rusaknya nama baik penggugat di mata masyarakat. 
Hakim Pengadilan Negeri memutuskan bahwa gugatan penggugat memenuhi unsur perbuatan melawan hukum yaitu perbuatan tergugat telah melanggar hak subyektif penggugat berupa hak atas kehormatan dan nama baik penggugat apalagi profesi penggugat adalah seorang guru. Perbuatan tergugat yang mengajak penggugat hidup bersama tanpa ikatan pernikahan tidak sepantasnya dilakukan tergugat sebagai seorang PNS yang seharusnya memberi contoh yang baik di masyarakat sehingga bertentangan dengan nilai-nilai kepatutan dalam masyarakat. Sementara itu hakim Pengadilan Tinggi membatalkan putusan hakim PN dan menyatakan perbuatan tergugat yang mengajak penggugat hidup bersama tersebut bukan merupakan tindakan yang merusak kehormatan dan nama baik penggugat mengingat status penggugat adalah janda cerai. Dengan demikian, pelanggaran terhadap hak subyektif penggugat tidak terpenuhi unsur-unsurnya. Akhirnya, hakim kasasi, menerima kasasi yang diajukan penggugat dan berpendapat perbuatan tergugat merupakan perbuatan melawan hukum karena tergugat sudah melanggar norma kesusilaan dan kepatutan dalam masyarakat.

Dari putusan hakim diatas baik hakim tingkat pertama, banding dan kasasi sama-sama berpendapat bahwa tidak dipenuhinya janji kawin itu merupakan perbuatan melawan hukum. Hakim tingkat pertama dan kasasi berpendapat unsur perbuatan melawan hukum terpenuhi sedangkan hakim tingkat banding berpendapat unsur perbuatan melawan hukum dalam kasus ini tidak dipenuhi (unsur pencemaran nama baik tidak ter- bukti).

Ada beberapa hal yang menarik dari kasus ini yakni terkait pertimbangan hakim PN dan hakim kasasi yang menyatakan perbuatan mengingkari janji kawin merupakan perbuatan melanggar hukum. Hakim PN yang menyatakan perbuatan tergugat merupakan perbuatan yang bertentangan dengan hak subyektif tergugat. Melanggar hak subyektif orang lain berarti melanggar wewenang khusus yang diberikan oleh hukum kepada seseorang. Wewenang khusus ini baik hak-hak yang bersifat perorangan/pribadi seperti nama baik, kehormatan dan kebebasan ataupun yang terkait hak atas harta kekayaan. Perbuatan pihak lain yang melanggar wewenang khusus yang diberikan norma hukum tersebut merupakan perbuatan bertentangan dengan hak subyektif orang lain. Dalam kasus ini, tergugat telah melanggar hak subyektif penggugat berupa hak pribadi yaitu nama baik. Hakim kasasi menilai perbuatan tergugat yang mengajak penggugat untuk hidup bersama dengan janji akan dikawini bertentangan dengan norma kesusilaan dan kepatutan yang hidup di masyarakat. Hakim kasasi lebih menekankan pertimbangannya pada perluasan penafsiran melawan hukum bahwa perbuatan melanggar hukum itu bukan hanya melanggar undang-undang tetapi juga melanggar hukum tidak tertulis berupa norma kesusilaan dan kepatutan yang ada di masyarakat.

Jika hakim kasasi menganut penafsiran yang sempit maka kasus Masudiati vs Gusti Lanang Rejeg tidak dapat dikatakan sebagai perbuatan melawan hukum karena tidak ada ketentuan undang-undang 
yang dilanggar oleh tergugat. Bahkan Pasal 58 KUH Perdata dengan tegas menyatakan bahwa janji-janji kawin tidak menimbulkan hak guna menuntut dimuka hakim akan berlangsungnya perkawinan, pun tidak guna menuntut penggantian biaya, rugi dan bunga, akibat kecederaan yang dilakukan terhadapnya, segala persetujuan untuk ganti rugi dalam hal ini adalah batal.

\section{Melina versus Kadarusman Putusan} dalam PutusanMahkamah Agung Nomor 935 K/Pdt/1998, tanggal 21 Desember 1999

Perkara ini bermula dari hubungan pacaran antara Melina dengan Hendrik Kadarusman, Hendrik membujuk Meliana untuk melakukan hubungan intim dengan janji apabila Meliana hamil maka ia berjanji akan mengawini Meliana. Akibat hubungan intim tersebut Meliana hamil dan menuntut Hendrik mengawininya tetapi Hendrik menolak. Meliana melaporkan Hendrik ke kepolisian . Perkara ini diperiksa secara pidana di Pengadilan Negeri Jakarta Pusat dengan No.689/1986/Pid/S/PN.JKT.Pst, Hendrik dinyatakan bersalah melakukan suatu perbuatan yang dikualifikasi sebagai "perbuatan tidak menyenangkan". Meliana kemudian mengajukan gugatan perdata terhadap Hendrik dengan dalil Hendrik telah melakukan perbuatan melawan hukum. Pengadilan negeri Jakarta Selatan melalui putusan No.349/Pdt.G/1995/ PN.Jkt.Sel. berpendapat bahwa perbuatan Tergugat yang menghindari tanggungjawab tersebut adalah bertentangan dengan asas kepatutan dalam dalam pergaulan hidup bermasyarakat yang mengakibat- kan kerugian baik moril maupun materiil pada Ibu dan anak yang dilahirkannya. Dengan demikian menurut pengadilan tergugat terbukti telah melakukan perbuatan melawan hukum yang mengakibatkan kerugian pada orang lain sehingga tergugat wajib memberi ganti kerugian.

Pengadilan Tinggi melalui Putusan No.519/Pdt/1996/PT.DKI membatalkan putusan Pengadilan Negeri dan menolak gugatan Penggugat dengan pertimbangan antara lain sebagai berikut:

Dalam bukti tambahan yang dilampirkan dalam memori banding, Hendrik menyatakan bahwa sejak April 1983, hubungan cinta mereka sudah putus, itu menunjukan bahwa anak Pengggugat bukanlah anak biologis Tergugat Pembanding sebagai akibat hubungan di luar nikah. Dengan tidak adanya hubungan biologis antara anak penggugat dengan tergugat maka tidak ada kewajiban bagi tergugat untuk membiayai/memberi nafkah kepada Pengggugat maka secara hukum tergugat tidak dapat dibebani kewajihan hukum karena anak yang lahir diluar nikah hanya mempunyai hubungan hukum dengan ibunya saja, tidak dengan bapak biologisnya. Hal ini sesuai dengan Pasal 43 (1) UU No.1 Tahun 1974.

Dalam tingkat kasasi Mahkamah Agung melalui Putusan No. $935 \mathrm{~K} /$ Pdt/1998 tanggal 21 Desember 1999 membatalkan putusan Pengadilan Tinggi tersebut diatas dengan mengambilalih pertimbangan hukum putusan pengadilan negeri yang dianggap sudah benar dan tepat dan dijadikan pertimbangan send- 
iri dalam mengadili perkara ini. Mahkamah Agung, menyatakan Tergugat telah melakukan perbuatan melawan hukum dan menetapkan kepada Tergugat untuk memberikan kepada Pengggugat dan anaknya sebuah rumah untuk berlindung yang layak seharga Rp. 161.000.000

Dalam kasus yang kedua ini, ada bujuk rayu dan janji kawin dari tergugat kepada penggugat agar penggugat bersedia berhubungan intim dengannya sehingga menyebabkan penggugat hamil. Hakim Pengadilan Negeri mengabulkan gugatan penggugat karena perbuatan bujuk rayu dan janji menikahi termasuk perbuatan melawan hukum yang telah menerbitkan kerugian bagi penggugat. Penggugat harus membesarkan anak yang lahir dari hubungan luar nikah dengan tergugat. Perbuatan ingkar janji tergugat dikategorikan sebagai perbuatan yang bertentangan dengan kepatutan dalam masyarakat. Nilai-nilai kepatutan dalam masyarakat tidak dapat menerima kelahiran seorang anak di luar nikah sehingga seharusnya tergugat menepati janjinya untuk mengawini penggugat. Atas ingkar janji tergugat hakim menghukum tergugat untuk memenuhi kewajiban hukumnya yakni memberikan nafkah kepada anak biologisnya. Hakim Pengadilan Tinggi membatalkan putusan hakim Pengadilan Negeri yang memerintahkan tergugat memberikan nafkah kepada anak biologis dengan dalil bahwa anak tersebut bukan anak biologis tergugat karena hubungan percintaan mereka sudah lama berakhir. Dengan demikian, tidak ada kewajiban hukum orang tua terhadap anak yang harus dipenuhi tergugat. Pertimbangan hakim menitikberatkan pada kewajiban memberi nafkah kepada anak bukan pada perbuatan melawan hukum tergugat yang membujuk dan menjanjikan pernikahan pada penggugat sehingga apabila terbukti anak tersebut bukan anak biologis tergugat maka gugur kewajiban hukumnya memberikan nafkah. Hakim kasasi membatalkan putusan Pengadilan Tinggi dan menguatkan putusan hakim Pengadilan Negeri. Perbuatan tergugat merupakan perbuatan melawan hukum yang bertentangan dengan kepatutan yang ada dalam masyarakat.

Sebagaimana kasus I, hakim PN dan hakim kasasi menganut penafsiran melawan hukum dalam arti luas, perbuatan tergugat merupakan perbuatan yang bertentangan dengan kepatutan dan kepantasan yang ada dalam masyarakat.

\section{Nofianti versus Hans Alexander Utomo Liu dalam Putusan Pengadilan Tinggi Banjarmasin Nomor 62/PDT/2017/PT BJM}

Kasus ini bermula dari hubungan asmara antara Penggugat dan Tergugat yang hidup bersama tanpa ikatan perkawinan sehingga Penggugat melahirkan seorang anak perempuan dan hamil kembali. Selama hidup bersama, Tergugat membiayai kehamilan, kelahiran dan nafkah dari anak yang lahir dari hubungan luar nikah tersebut. Tergugat menjanjikan mengawini Tergugat setelah terlebih dahulu menceraikan isterinya. Ternyata Tergugat tidak memenuhi janjinya untuk menceraikan isterinya dan mengawini Penggugat. Saudara Nofianti kemudian menggugat Hans Alexander Liu ke Pengadilan Negeri Banjarmasin, dengan mendalilkan bahwa: pertama, Perbuatan Melawan Hukum 
dalam arti onrechtmatige daad, dalam bentuk melanggar norma susila yaitu perbuatan Tergugat menghamili Penggugat dengan janji kawin yang kemudian dingkarinya; dan kedua, Perbuatan Melawan Hukum dalam arti onrechtmatige daad, dalam bentuk melanggar hak subyektif Penggugat yaitu melakukan penganiayaan terhadap diri penggugat.

Pada Pengadilan Tingkat pertama gugatan Penggugat di tolak lewat $\mathrm{Pu}-$ tusan Pengadilan Negeri Nomor 9/ PDT.G/2017/PN BJM dengan pertimbangan bahwa : Pasal 1365 KUHPerdata tidak dapat diterapkan dalam kasus ini. Demikian juga Yurisprudensi Mahkamah Agung RI No.552K/SIP/1994 dan Putusan Mahkamah Agung RI No.3191K/ PDT/1984 tidak dapat diterapkan dalam kasus ini. Hal ini didasarkan pada fakta bahwa Tergugat tetap menanggung biaya hidup anak yang dilahirkan penggugat dan hubungan antara mereka adalah hubungan suka sama suka antara laki-laki dewasa dan perempuan dewasa. Penggugat juga sudah mengetahui bahwa Tergugat sudah menikah dan mempunyai seorang anak. Putusan Pengadilan Negeri Banjarmasin tersebut kemudian dikuatkan oleh Pengadilan Tinggi Banjarmasin lewat Putusan No.62/PDT/2017/PT.BJM.

Dalam kasus yang ketiga ini, unsur perbuatan melawan hukum tidak terpenuhi karena tidak terbit kerugian bagi penggugat. Meskipun tergugat mengingkari janjinya untuk mengawini penggugat tetapi tergugat tetap membiayai kehidupan penggugat dan anak yang lahir dari hubungan mereka. Pasal 1365 KUH Perdata mensyaratkan semua unsur yang terdapat dalam pasal tersebut harus ter- penuhi yakni adanya perbuatan yang melanggar hukum, terdapat unsur kesalahan dari pelaku, korban menderita kerugian sebagai akibat dari perbuatan melanggar hukum tersebut, barulah Pasal 1365 KUH Perdata dapat diterapkan. Dari kasus ini memperlihatkan bahwa tidak semua janji kawin yang dingkari merupakan perbuatan melawan hukum.

\section{Dewi Vivi Yanti, SE versus Yulirwan,S. Pd. dalam Putusan Mahkamah Agung Nomor 1860 K/PDT/2011}

Kisah bermula dari hubungan percintaan antara Pengggugat yang berstatus gadis dengan Tergugat berstatus duda 4 anak. Hubungan percintaan mereka berlangsung selama 1,5 tahun terhitung dari Mei 2007 sampai dengan Agustus 2008. Hubungan mereka dikhetahui juga oleh guru-guru yang lain ditempat mereka sama-sama mengajar. Pada tanggal 10 Pebruari 2008 atas bujukan dan janji tergugat yang begitu meyakinkan bahwa ia sangat mencintai penggugat dan akan segera menjadikan tergugat isterinya maka atas bujukan dan janji tersebut Penggugat dengan sangat terpaksa bersedia berhubungan intim dengan tergugat. Akibat hubungan intim tersebut Penggugat kehilangan keperawanannya.

Pengggugat mendesak Tergugat untuk segera menikahinya karena tidak mau terjadi sesuatu dengannya (hamil) tapi tergugat selalu mengelak dengan alasan masih mengumpulkan uang untuk biaya pernikahan. Tanggal 8 Juli 2008 atas desakan Penggugat, Tergugat menyuruh Penggugat datang kerumahnya untuk menemui sdra Harmen (Abang sepupu Tergugat) dan Tergugat minta kepada 
Penggugat untuk menyampaikan rencana pernikahan pada keluarganya. Selain Tergugat, kakak sepupu tergugat, hadir juga pada saat itu sdr Tin (kakak kandung tergugat), Sdr. Anjeua (keponakan tergugat), sdr Yetti (teman sesame guru) di SMP Negeri 18 Riau).Penggugat kemudian menyampaikan tentang rencana pernikahannya dengan tergugat. Sdr. Harmen kemudian mengatakan bahwa supaya diadakan pertemuan anatra keluarga penggugat dan keluarga tergugat untuk membicarakan pernikahan tersebut. Tanggal 18 Juli 2008 pengggugat memberitahu tergugat via sms bahwa keluarga penggugat sudah siap untuk membicarakan rencana pernikahan tersebut dan kapan rencana pertemuan itu diadakan. Tergugat menjawab, sabar dulu nanti akan diberitahukan kapan waktu pertemuan dengan keluarga tergugat.Karena tidak ada kejelasan tentang waktu pertemuan, maka tanggal 20 Juli 2008, penggugat datang kerumah tergugat untuk menanyakan kapan pastinya pertemuan keluarga diadakan. Tergugat menjawab, nanti dibicarakan setelah Abang balik dari Perawang. Sambil menunggu tergugat pulang dari Terawang, penggugat membersihkan rumah tergugat yang kotor berantakan. Pada waktu membersihkan rumah tergugat, pengggugat sangat terkejut karena menemukan sehelai foto copy surat persetujuan menikah atas nama Yulirwan ( Tergugat) dengan seorang perempuan bernama Yusmiati.Penggugat sangat shock karena tergugat mengingkari janjinya untuk menikahi penggugat dan malah akan menikahi wanita lain. Pengggugat minta penjelasan terhadap kebenaran fotocopy surat persetujuan menikah tersebut ke- pada Ernawati siteri Harmen dan Harmen sendiri. Sdr. Harmen menelpon tergugat untuk menanyakan kebenaran isi surat tersebut, oleh tergugat dijawab bahwa itu tidak benar dan tergugat minta agar surat tersebut dibuang saja.dan pada saat itu sdr Ernawati merobek dan membuang suarat tersebut ke tempat sampah.

Tergugat kemudian melaporkan pengggat ke Polsek Sukajadi dengan tuduhan penggugat telah mencuri fotocopy surat persetujuan menikah tergugat dengan Yusmiati. Atas laporan tersebut, pengggugat ditahan selama 17 hari di Polsek Sukajadi Pekan baru dan selama pengggugat ditahan, tergugat melangsungkan pernikahannya dengan Yusmiati. Menurut hemat pengggugat, tindakan tergugat hanya akal-akalan/rekayasa supaya bebas dari tanggungjawab menikahi pengggugat.

Putusan PN Pekan Baru Nomor 959/ Pid B/2009/PN.PBR tanggal 7 April 2009 membebaskan penggugat dari segala dakwaan karena tidak terbukti melakukan tindak pidana pencurian sebagaimana tuduhan tergugat. Penggugat kemudian mengggugat tergugat karena sudah membawa kerugian baik materiil maupun immateriil. Kerugian imateriiil karena telah mengambil keperawanan penggugat dengan janji mengawini yang kemudian diingkari. Kerugian materiiil lainnya adalah bayar jasa advokad (40 juta) dan gugatan a quo untuk memperjuangkan keadilan atas ingkar janji (wanprestasi) tergugat untuk menikahi penggugat. Kerugian immateriil : penggugat merasa dipermalukan harkat dan martabatnya sebagai seorang wanita sebesar 5 (lima) milyar. Pengggugat menuntut tergugat atas dasar 
wanprestasi. Putusan Pengadilan Tinggi Pekan Baru Nomor 198/PDT/2010/PTR tanggal 3 Maret 2011 menguatkan putusan PN Pekan Baru, menolak gugatan penggugat. Kemudian pengggugat mengajukan kasasi dengan alasan Judex Facti (PN dan PT) salah menerapkan hukum atau melanggar hukum dan putusan Judex Facti tidak cukup pertimbangan.

Mahkamah Agung berpendapat, alasan kasasi tidak dapat dibenarkan, judex factie tidak salah menerapkan hukum dan pengggugat tidak dapat membuktikan dalil-dalilnya bahwa pengggugat telah menyerahkan keperawanannya pada tergugat karena tergugat berjanji akan menikahi penggugat. Pembuktian yang bersifat penghargaan tentang suatu kenyataan, tidak dapat dipertimbangkan dalam pemeriksaan tingkat kasasi. Atas pertimbangan diatas, MA menilai putusan judex factie dalam perkara ini tidak bertentangan dengan hukum/dan/atau undang-undang maka permohon kasasi yang diajukan pemohon kasasi Dewi Vivi Yanti harus ditolak.

Ditolaknya gugatan penggugat dalam kasus ini menurut penulis ada beberapa hal yang menyebabkannya :

1. Kesalahan dalam gugatan. Seharusnya gugatan tersebut tidak didasarkan atas wanprestasi tetapi atas dasar perbuatan melawan hukum.

2. Kehilangan keperawanan karena bujuk rayu atas janji kawin tersebut merupakan kerugian immateriil. Kerugian immateriil hanya dikenal dalam perbuatan melawan hukum sedangkan dalam wanprestasi kerugian yang dapat dituntut adalah kerugian yang senyatakannya yang diderita ko- rban yakni kerugian yang dapat dinilai dengan uang.

3. Judex factie dan hakim kasasi berpendapat bahwa yang menjadi dasar ditolaknya gugatan penggugat adalah penggugat tidak dapat membuktikan dalil-dalilnya bahwa ia bersedia menyerahkan keperawanannya karena janji kawin yang diucapkan tergugat padanya. Masalah pembuktian ini memang sulit karena janji kawin tersebut diucapkan secara lisan tidak ada bukti tertulis. Ketiadaan saksi juga makin mempersulit dalam pembuktian sehingga dalam kasus-kasus seperti ini gugatan penggugat rentan ditolak.

4. Dalam pertimbangannya hakim judex factie maupun hakim kasasi tidak menyinggung bahwa tidak dipenuhinya janji kawin adalah perbuatan melawan hukum bukan tindakan wanprestasi. Dengan kata lain, hakim menerima saja dalil gugatan atas dasar wanprestasi. Seandainya hakim berpendapat bahwa itu bukan wanprestasi tetapi perbuatan melawan hukum maka seharusnya hakim menyatakan bahwa gugatan dari penggugat tidak dapat diterima (niet Ontvankelijke verklaard/NO), karena salah dasar gugatan.

\section{Lyaniza Meliza Buntu vs Daud Sury- aningrat Tarupadang dalam Putusan Pengadilan Negeri Makasar Nomor 82 Pdt G.2014.PN Makasar}

Setelah melewati masa pacaran, Tergugat dan penggugat sepakat untuk melanjutkannya ke jenjang pernikahan. Acara lamaran menurut masyarakat adat 
Toraja telah dilangsungkan pada tanggal 17 Oktober 2013 yang dilaksanakan di rumah penggugat. Setelah acara lamaran, kemudian dibentuk panitia untuk mempersiapkan pernikahan yang anggotanya berasal dari keluarga tergugat dan penggugat. Rapat panitia pada tanggal 19 Januari 2014 menyepakati pernikahan akan dilangsungkan tanggal 22 Pebruari 2014 Dalam rangka pernikahan tersebut: undangan sudah disebar, DP Gedung tempat pernikahan sudah dibayar, cincin pengantin, pakaian pengantin dan keperluan-keperluan lainnya yang terkait pernikahan. Dan dalam rencana pernikahan tersebut, penggugat mengeluarkan biayabiaya yang besar seperti untuk perlengkapan kamar pengantin, catering, sewa tenda dan keperluan lainnya sebesarRp. 92.054.000. Setelah semua persiapan berjalan dengan baik untuk pernikahan tanggal 22 Pebruari ternyata Tergugat I dan Tergugat II (ayah tergugat I), tibatiba membatalkan pernikahan tanpa alasan yang jelas. Tergugat II, lalu membatalkan pesanan gedung, pesanan salon yang sudah dibooking. Akibat pembatalan tersebut menimbulkan komplain dari pihak gedung (Clarion Hotel Makasar) dan pihak salon. Pembatalan pernikahan tersebut adalah tindakan wanprestasi, yang telah menimbulkan kerugian bagi penggugat baik kerugian materiil maupun kerugian immateriil sebab penggugat sebagai seorang dokter telah dikenal luas dan juga memiliki status sosial yang tinggi dalam pergaulan masyarakat Toraja. Penggugat menggugat tergugat atas dasar wanprestasi dan menuntut kerugian materiil sebesar 92.054.000 dan ganti rugi immateriil karena merasa dipermalu- kan. Penggugat mendapat respon negatif dalam pergaulan sosial. Penggugat tidak tentram bahkan mengalami tekanan psikis. Untuk itu penggugat menuntut ganti rugi immateriil sebesar Rp.10 milyar.

Hakim Pengadilan Negeri Makasar dalam putusannya menyatakan :

- Mengabulkan gugatan penggugat sebagian;

- Menyatakan menurut hukum bahwa tindakan tergugat I yang membatalkan pernikahan yang telah disepakati merupakan perbuatan cidera janji (wan prestasi),

- Menyatakan bahwa segala tuntutan hukum dari pihak yang merasa dirugikan dalam hal ini pemilik dari Clarion Hotel Makasar dan salon adalah tanggungjawab tergugat I dan tergugat II;

- Menghukum tergugat I dan Tergugat II untuk membayar ganti rugi secara tunai kepada penggugat biaya-biaya yang dikeluarkan dalam rangka persiapan pernikahan tanggal 22 Pebruari 2014 berdasarkan nota-nota yang ada sebesar Rp.35.070.000;

- Ganti rugi immateriil akibat perbuatan wanprestasi yang dilakukan tergugat I yang membatalkan secara sepihak rencana pernikahan dengan penggugat sebesar 1 milyar rupiah

Gugatan terhadap pembatalan perkawinan diajukan atas dasar wanprestasi sudah sesuai dengan ketentuan Pasal 58 ayat (2) KUH Perdata menyatakan :

“ Jika namun itu pemberitahuan kawin kepada pegawai catatatan sipil telah diikuti dengan pengumuman kawin, maka yang demikian itu dapat menimbulkan 
alasan guna menuntut penggantian biaya, rugi dan bunga, berdasar atas kerugiankerugian yang nyata kiranya telah diderita oleh pihak satu mengenai barang-barangnya, disebabkan kecederaaan pihak lain......",

Menilik dari rumusan Pasal 58 ayat (2) KUH Perdata tersebut, gugatan terhadap perbuatan tergugat yang membatalkan perkawinannya merupakan perbuatan wanprestasi bukan perbuatan melawan hukum. Dikatakan sebagai wanprestasi karena rencana perkawinan tersebut sudah diberitahukan kepada Kantor Catatan Sipil dan juga diikuti dengan pengumuman kawin. Apabila kasus pembatalan perkawinan ini, digugat atas dasar perbuatan melawan hukum niscaya gugatan penggugat akan ditolak karena rumusan pada Pasa 158 ayat (1) KUH Perdata, baru sebatas janji kawin yang hanya melibatkan para pihak saja belum melibatkan pihak ketiga (pegawai pencatat perkawinan).

\section{PENUTUP}

Perbuatan mengingkari janji kawin merupakan perbuatan melawan hukum bukan tindakan wanprestasi. Hal ini didasari oleh beberapa hal yaitu: (a) janji kawin terletak di lapangan hukum keluarga bukan di lapangan hukum harta kekayaan. Janji kawin bukanlah perjanjian kebendaan tetapi lebih pada perjanjian yang bersifat personal; (b) tidak memenuhi syarat sahnya perjanjian khususnya syarat obyektif yakni suatu hal tertentu dan causa yang halal. Perjanjian yang tidak memenuhi syarat obyektif batal demi hukum; (c) bertentangan dengan Pasal 58 ayat (1) KUH Perdata. Oleh karena itu, janji kawin yang diingkari hanya dapat digugat atas dasar perbuatan melawan hukum karena memenuhi unsur-unsur yang terdapat dalam Pasal 1365
KUH Perdata yaitu: (a) perbuatan ingkar janji dalam janji kawin masuk kategori perbuatan melawan hukum yakni bertentangan dengan norma kesusilaan dan kepatutan dalam masyarakat; (b) perbuatan pelaku memenuhi unsur kesalahan dalam bentuk kesengajaan dimana pelaku menyadari sepenuhnya akan akibat dari perbuatannya tersebut; (c) kerugian yang dialami korban dapat berupa kerugian materiil dan kerugian immaterii. Kerugian terbesar adalah dalam bentuk kerugian immateriil karena adanya tekanan mental dalam bentuk rasa malu karena nama baiknya tercemar dimata masyarakat; dan (d) ada hubungan kausal antara janji kawin yang diucapkan pelaku dengan kerugian yang diderita oleh korban. Tanpa adanya janji yang diucapkan pelaku si korban tidak akan bersedia mengikuti keinginan dari pelaku. Penafsiran yang digunakan hakim dalam memaknai ketentuan Pasal 58 KUH Perdata merupakan penafsiran melawan hukum dalam arti yang luas. Perbuatan melawan hukum termasuk perbuatan yang bertentangan dengan norma kesusilaan dan kepatutan dalam masyarakat. Selain itu, terdapat kerancuan pada praktik di pengadilan dalam kasus janji kawin. Gugatan yang seharusnya didasarkan atas perbuatan melawan hukum digugat atas dasar wanprestasi, demikian juga sebaliknya.

Dengan banyaknya kasus janji kawin yang digugat ke pengadilan maka pasangan yang sedang menjalin hubungan asmara berhati-hati dalam mengumbar janji kawin karena bisa berbuah gugatan apabila janji tersebut tidak dipenuhi. Seharusnya ada konsistensi dalam putusan pengadilan terkait dasar gugatan janji kawin dan untuk para advokad agar lebih jeli dalam memilih dasar gugatan yang pas agar jangan sampai kliennya dirugikan. 


\section{BIBLIOGRAFI}

Agustina, Rosa. 2003. Perbuatan Melawan Hukum. Jakarta: PPS-FH UI.

Badrulzaman, Mariam Darus. 1983. KUH Perdata Buku III Hukum Perikatan Dengan Penjelasan. Bandung: Alumni.

Khairandy, Ridwan. 2004. Itikad Baik Dalam Kebebasan Berkontrak. Jakarta: PPS-FH UI.

Fuady, Munir. 2010. Perbuatan Melawan Hukum Pendekatan Kontemporer. Bandung: Citra Aditya Bakti.

Meliala, S Djaja. 2014. Hukum Perdata Dalam Perspektif BW. Bandung: Nuansa Aulia.

Muhammad, Abdul Kadir. 1990. Hukum Perikatan. Bandung: Citra Aditya Bakti.

Muhammad, Abdul Kadir. 1993. Hukum Perdata Indonesia. Bandung: Citra Aditya Bakti.

Prodjodikoro, Wirjono. 2000. Perbuatan Melanggar Bukum Dipandang Dari Sudut Hukum Perdata. Bandung: Mandar Maju.
Simanjuntak, P.N.H. 2015. Hukum Perdata Indonesia. Jakarta: Kencana.

Syahrani, Riduan. 2006. Seluk Beluk Hukum Perdata. Bandung: Alumni.

\section{Peraturan Perundang-undangan}

Kitab Undang-undang Hukum Perdata (Staatsblad Tahun 1847 Nomor 23)

\section{Putusan Pengadilan}

Putusan Mahkamah Agung Nomor 3191 K/ PDT/1984.

Putusan Mahkamah Agug Nomor $935 \mathrm{~K} /$ PDT/1998.

Putusan Mahkamah Agung Nomor $1860 \mathrm{~K} /$ PDT/2011.

Putusan Pengadilan Tinggi Banjarmasin Nomor 62/PDT/2017/PT.BJM.

Putusan Pengadilan Negeri Makasar Nomor 82 PDT G.2014. PN Makasar. 